\title{
REMOVAL OF ZINC AND ITS EFFECT ON SOME MACROMOLECULES AND ULTRASTRUCTURE OF PTEROCLADIA CAPILLACEA AND SARGASSUM HORNSCHUCHII
}

\author{
Nadia H. Noaman ${ }^{1}$, Suzan I. Ahmed ${ }^{2}$, Eman M. Fakhry ${ }^{1}$, Magda A. \\ Shafik $^{2}$ and Wafaa M. Menesi ${ }^{2}$ \\ ${ }^{1}$ Department of Botany and Microbiology, Faculty of Science, Alexandria \\ University, Egypt. \\ ${ }^{2}$ Department of Biological and Geological Sciences, Faculty of Education, \\ Alexandria University, Egypt
}

\begin{abstract}
The removal process of zinc from an aqueous solution illustrated a good biosorption of metal by both algal fresh materials. However, the highest removal percentage of zinc by $P$. capillacea was found to be greater than that by S. hornschuchii. The removal of zinc by $P$. capillacea and $S$. hornschuchii increased with increase in contact time up to 3 and 5 hours, respectively. It decreased by very slight rate within 4-12 hours for $P$. capillacea and within 6-12 hours for S. hornschuchii. This study evaluated the effect of zinc on growth, amino acids, fatty acids and protein contents of Pterocladia capillacea and Sargassum hornschuchii .In this investigation $P$. capillacea tolerates higher concentrations of heavy metals as compared to S.hornschuchii . Exposure of $P$. capillacea to zinc decreased all amino acids except tyrosine, phenylalanine and proline which increased. All amino acids of S.hornschuchii increased by exposure to zinc except glycine, alanine, valine, leucine, isoleucine, phenylalanine and methionine, which decreased. The protein content of $P$. capillacea was inhibited by zinc, while percentage of protein content of S.hornschuchii increased more than three times by exposure to zinc. All fatty acids of $P$. capillacea increased by exposure to zinc except $\mathrm{C}_{16: 1}$, which decreased

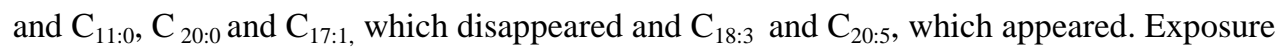
of S.hornschuchii to zinc causes the increase of the contents of all fatty acids except $\mathrm{C}_{6: 0}$, $\mathrm{C}_{10: 0,}, \mathrm{C}_{18: 0}$ and $\mathrm{C}_{18: 2,}$, which decreased, $\mathrm{C}_{23: 0}$ and $\mathrm{C}_{20: 3}$, which appeared. Concerning the ultrastructure of $P$. capillacea grown in zinc solution for hours, it showed destructive irregularity of cell wall, disordering of cell inclusions, appearance of vacuoles and aggregation of cell components in a dense black manner inside the cell, while examination of S. hornschuchii ultra-structure with zinc showed destructive change in thyllakoids arrangement and slightly deviation of protoplast from the cell wall.
\end{abstract}

Keywords: Uptake, zinc, algae, amino acid, fatty acid, ultrastructure. 


\section{Introduction}

Heavy metal toxicity arises when metals bond non- specifically with coordination sites of important biological molecules such as enzymes and other proteins, thereby altering normal metabolic functions (Sunda, 1989). Toxcity can also be related to oxidative stress induced in living systems either by increasing concentrations of reactive oxygen species or by reducing cellular antioxidant capacity (Pinto et al., 2003). It is generally accepted that heavy metal will interact with chemical and biological processes and cause changes within the biota. Various reviews have provided a wide coverage of heavy metal toxicity in algae (Noaman $\boldsymbol{e t}$ al., 2001, 2003 and Debelius et al., 2009).

Exposure to heavy metal contamination has been found to cause kidney damage, liver damage and anemia in low doses, and in high concentrations, they can be carcinogenic (Carson et al., 1986). Minor zinc exposure was found to cause irritability, muscular stiffness, loss of appetite and nausea (Bhattacharya $\boldsymbol{e t}$ al., 2006).

Many industries, especially electroplating, battery and plastic manufacturing release as zinc in wastewater. Zinc is an essential element for enzyme activators in humans, but it is toxic at level of 100-500 mg/day and it is a known carcinogen (Volesky and Holan, 1995).

The effect of this environmental pollutant on the growth of Pterocladia capillacea and Sargssum hornschuchii, amino acids, fatty acids and protein contents were performed. The cellular ultrastructural alterations were also monitored by transmission electron microscopy as a response of exposure to the pollutant.

\section{Materials and Methods}

\section{Algal materials:}

Healthy samples of Pterocladia capillacea and Sargassum hornschuchii were collected from about one and half meter depth of Mediterranean Sea shore of Alexandria, Abu-Qir district, beginning of May (2009) and throughout the practical study period. The algae were transported back to laboratory. Some algal biomasses were cultivated in Sea water for batch biosorption and others were dried. For dry samples, the algal biomass was washed in running distilled water 2-3 times, and then eventually kept on a filter paper to reduce the water content. 
The biomass was then air dried for 12 hours followed by drying in an oven at 50 ${ }^{\circ} \mathrm{C}$ till constant weight. Subsequently, it was ground, sieved and kept in glass container till use.

\section{Chemicals:}

All chemical reagents employed in this study were products of sd Fine Chem. Limited, India.

\section{Preparation of metal solution:}

$1000 \mathrm{mg} . \mathrm{l}^{-1}$ stocks of zinc [Zn (II)] solutions for all experiments were prepared by dissolving its corresponding salts zinc chloride $\left[\mathrm{ZnCl}_{2}\right]$ in deionized distilled water.

\section{Analysis of metal solution:}

The concentrations of chromium or zinc were quantified using Atomic Absorption Spectrophotometer (Perkin Elmer 2380). The instrument was initially calibrated before each use with standard solutions. The samples were diluted, whenever necessary, with distilled water to improve accurate estimation.

\section{Batch biosorption studies:}

Batch biosorption studies were carried out using Pterocladia capillacea and Sargassum hornschuchii as biosorbents. All biosorption experiments were conducted in $500 \mathrm{ml}$ Erlenmeyer flasks by mixing $1 \mathrm{~g}$ of fresh algal biomass or $0.4 \mathrm{~g}$ of dry algal biomass with $100 \mathrm{ml}$ metal solution of specific concentration. The metal concentration prepared by adequate dilution of its stock solution using Sea water biomass. The flasks were previously rinsed with $\mathrm{HNO} 3$ in order to remove any metal that remained adsorbed on the glass wall. The mixtures were periodically agitated for desired time, then the algal materials were filtered through filter paper and the final concentration of zinc in filtrates was determined by Atomic Absorption Spectrophotometer. All the experiments were performed at natural light condition $\left(16 \mathrm{~h}\right.$. light $/ 8 \mathrm{~h}$. dark) and room temperature $\left(29 \pm 2^{\circ} \mathrm{C}\right)$ with two replicates. Mean values were reported and controls without addition of zinc were run in parallel.The fresh biological materials were subjected to fatty acids, amino acids and protein analyses, as well as T.E.M (Transmission Electron Microscope) investigation. The Sea water was analyzed for its zinc concentrations and the detected value was $0.024 \mathrm{mg} \cdot \mathrm{l}^{-1}$. The amount of metal sorbed by algae at equilibrium, $q\left(\mathrm{mg} \cdot \mathrm{g}^{-1}\right)$, which represents the heavy metal uptake was calculated from the difference in metal concentration in the aqueous phase before and after 
sorption according to the following equation (Hashim \& Chu, 2004 and Basha et al., 2008):

$$
\text { (Metal uptake) } q=\frac{\mathrm{Ci}-\mathrm{Cf}}{\mathrm{w}} \times V
$$

Where $V$ is the volume of metal solution (1), Ci and Cf are the initial and final concentration of metal in solution (mg. $\left.1^{-1}\right)$, respectively and $W$ is the mass of fresh or dried alga $(\mathrm{g})$. ( $\mathrm{Ci}-\mathrm{Cf}$ ) represents the concentration of metal sorbed by algae at equilibrium, (mg. $\left.\mathrm{l}^{-1}\right)$. The removal percentage of the heavy metal by studied macroalgae was estimated from the following equation:

$$
\text { Removal percentage of metal } \%=\frac{\mathrm{Ci}-\mathrm{Cf}}{\mathrm{Ci}} \times 100
$$

\section{Amino acids determination :}

Amino acids determination was performed according to the method of Winder and Eggum (1966). Oxidation with acid, to protect methionine and cystine from destruction during acid hydrolysis, followed by acid hydrolysis were carried out in closed conical flask for determining all amino acids other than tryptophan. A sample of $20-30 \mathrm{mg}$ of fresh algal biomass was weighed in the conical flask and $5 \mathrm{ml}$ of performic acid was added. The flask was closed and placed in ice water bath for 16 hours. Sodium metabisulfate was added, $25 \mathrm{ml}$ $\mathrm{HCl} 6 \mathrm{~N}$ was added to the oxidized mixture. The flask was placed in an oven at $110^{\circ} \mathrm{C}$ for 24 hours. The flask was then opened and the content evaporated for dryness in a rotary evaporator. A suitable volume of sodium buffer ( $\mathrm{pH} 2.2)$ was added to the dried film of hydrolyzed sample. After all soluble material completely dissolved, the sample is ready for analysis.

Amino acid analyzer program:

Amino acids were separated by using SYKAM amino acids analyzer, version 6.8.

\section{Fatty acids determination:}

The fatty acids of the two-studied algae were determined according to (Radwan, 1978). $25 \mathrm{mg}$ algal sample added with $2.5 \mathrm{ml}$ methanolic sulphuric acid ( $1 \mathrm{ml}$ cocentrated sulphuric acid with $100 \mathrm{ml}$ methanol hydroxide) and $1 \mathrm{ml}$ benzene in a $10 \mathrm{ml}$ tube, closed well and then was placed in oven at $90^{\circ} \mathrm{C}$ for one and half hour. Allowed to cool, then $4 \mathrm{ml}$ distilled water and $2.5 \mathrm{ml}$ petroleum ether were added and the tube was shaken. The ether layer was separated in a tube, evaporated till dryness. $50 \mathrm{ml} \mathrm{n}$ hexane was added at injection in GC. 
Chromatographic analysis of fatty acids was performed on gas liquid chromatography, which equipped with a flame ionization detector (FID) and fitted with HP-5 column.

\section{Protein estimation:}

The protein contents of algal biomasses were estimated from the organic nitrogen content determined by Kjeldahl procedure according to Pearson's Chemical Analysis of Foods (Egan et al., 1981). Conversion factor for nitrogen to crude protein was based on the average nitrogen content of proteins found in particular foods (Jones, 1931). FAO/WHO (1973) recommended factor 6.25.

\section{Transmission Electron Microscope:}

Before and after the biosorption process $P$. capillacea and $S$. hornschuchii biomasses were harvested, fixed and prepared for examination by JEOL 100CX,TEM.

\section{0. $\mathbf{p H}$ determination:}

Before the adsorption study, the $\mathrm{pH}$ of the chromium or zinc solution was adjusted to required value with $0.1 \mathrm{M} \mathrm{HCl}$ and $0.1 \mathrm{M} \mathrm{NaOH}$ solutions using a $\mathrm{pH}$ meter (model WPA LINTON CAMBRIDGE UK. CD 620).

\section{Statistical analysis:}

Statistical analysis employed SPSS version 10.0 for testing significance of differences between treatments at the 0.05 probability level $(P=0.05)$. Most of experiments were tested with analysis of variance (ANOVA) and some of them were tested with Student's t-test.

\section{Results and Discussion}

\section{Effect of metal concentration at different time periods:}

The biosorption efficiencies of $P$. capillacea and $S$. hornschuchii as a function of contact time and concentration of zinc solution were studied and the results were shown in Fig. 1-4. The results showed that about $56.70-75.18 \%$ and $54.15-62.72 \%$ of zinc removal (within the concentration ranges of $25-100 \mathrm{mg} . \mathrm{l}^{-1}$ ) was attained by $P$. capillacea and S. hornschuchii, respectively after 12 hours. 
Further increase in contact time has negligible and non-significant effect on the removal of metal by studied biosorbents. Therefore optimum zinc biosorption by both algal biomasses was occurred at 12 hours.

The results of Fig. 1-4 also showed that uptake of zinc by both biosorbents increased significantly with elevation of metal concentration from 25 to $100 \mathrm{mg} . \mathrm{l}^{-1}$ at the same time period. In case of $P$. capillacea, uptake of zinc increased from 1.7 to $5.67 \mathrm{mg} . \mathrm{g}^{-1}$ after 12 hours (optimum contact time) while in case of $S$. hornschuchii, it increased from 1.56 to $5.41 \mathrm{mg} \cdot \mathrm{g}^{-1}$. On the other hand, $P$. capillacea was effective at $50 \mathrm{mg} . \mathrm{l}^{-1}$ zinc concentration with highest removal percentage of $75.18 \%$, followed in decreasing order by concentrations $25 \mathrm{mg} . \mathrm{l}^{-1}$ and $100 \mathrm{mg} \cdot \mathrm{l}^{-1}$. S. hornschuchii demonstrated the highest removal percentage of $62.72 \%$ at lowest metal concentration $\left(25 \mathrm{mg} . \mathrm{l}^{-1}\right)$, which decreased slowly with increase in zinc concentration. Therefore the rest biosorption experiments for zinc by P.capillacea and S. hornschuchii were performed using 50 and $25 \mathrm{mg} . \mathrm{l}^{-1}$, respectively.

The removal process of zinc from an aqueous solution illustrated a good biosorption of metal by both algal fresh materials. However, the highest removal percentage of zinc by $P$. capillacea was found to be greater than that by $S$. hornschuchii.

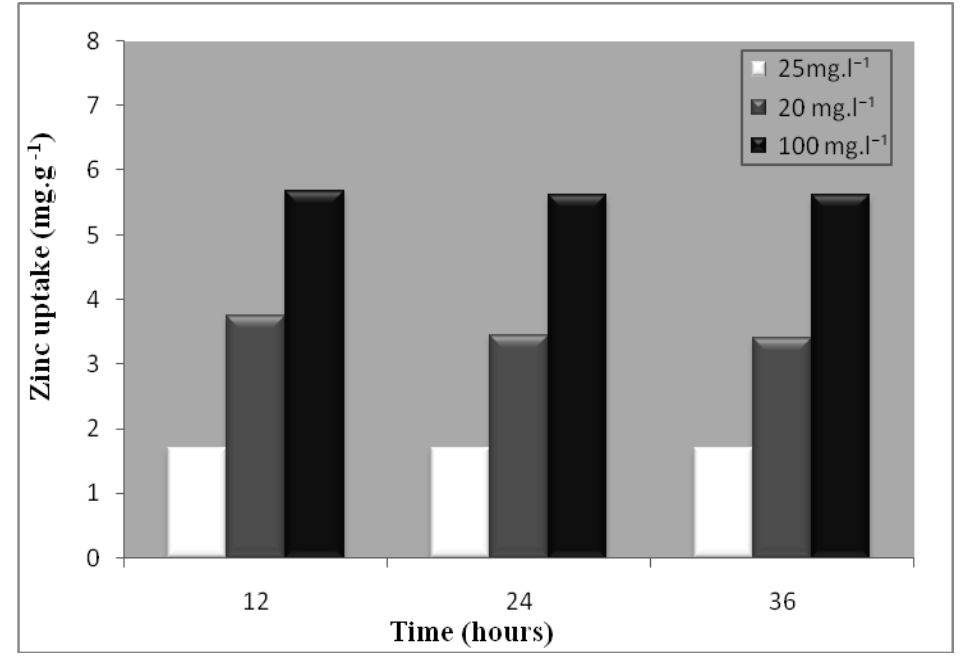

Fig.1: Uptake of zinc by Pterocladia capillacea fresh biomass at different concentrations after 12, 24 and 36 hours. 
Removal of zinc and its effect on some macromolecules and ultrastructure of Pterocladia capillacea ......

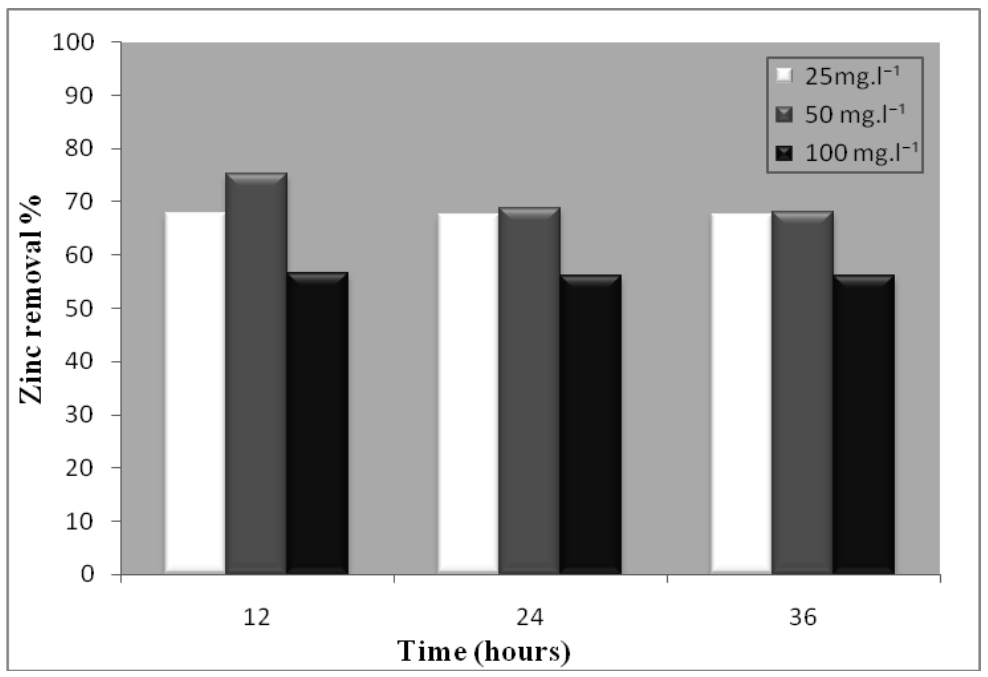

Fig.2: Removal percentage of zinc by Pterocladia capillacea fresh biomass at different concentrations after 12, 24 and 36 hours.

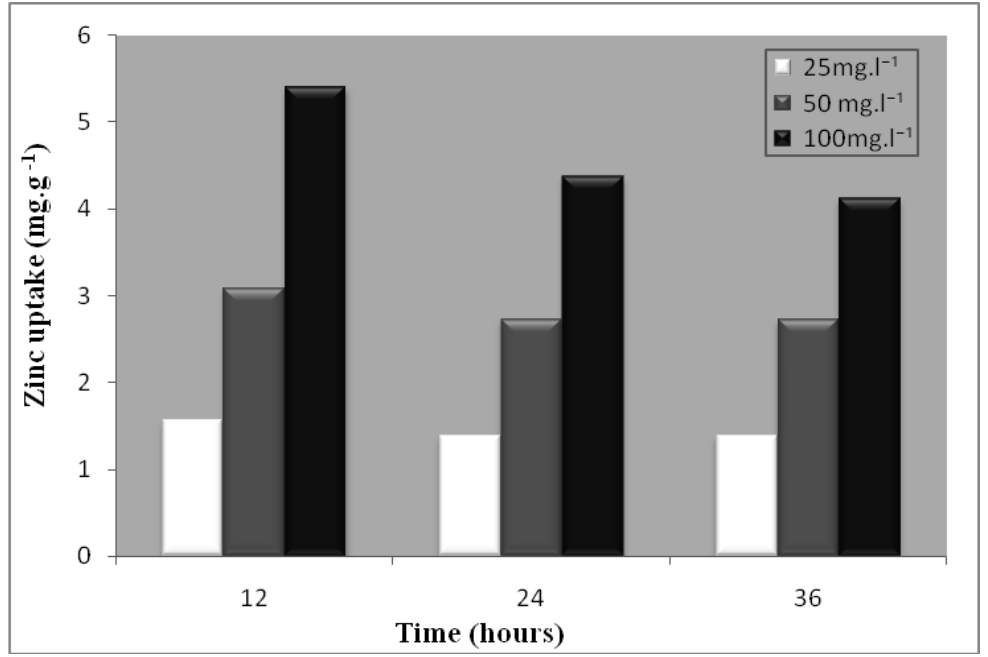

Fig. 3: Uptake of zinc by Sargassum hornschuchii fresh biomass at different concentrations after 12, 24 and 36 hours. 


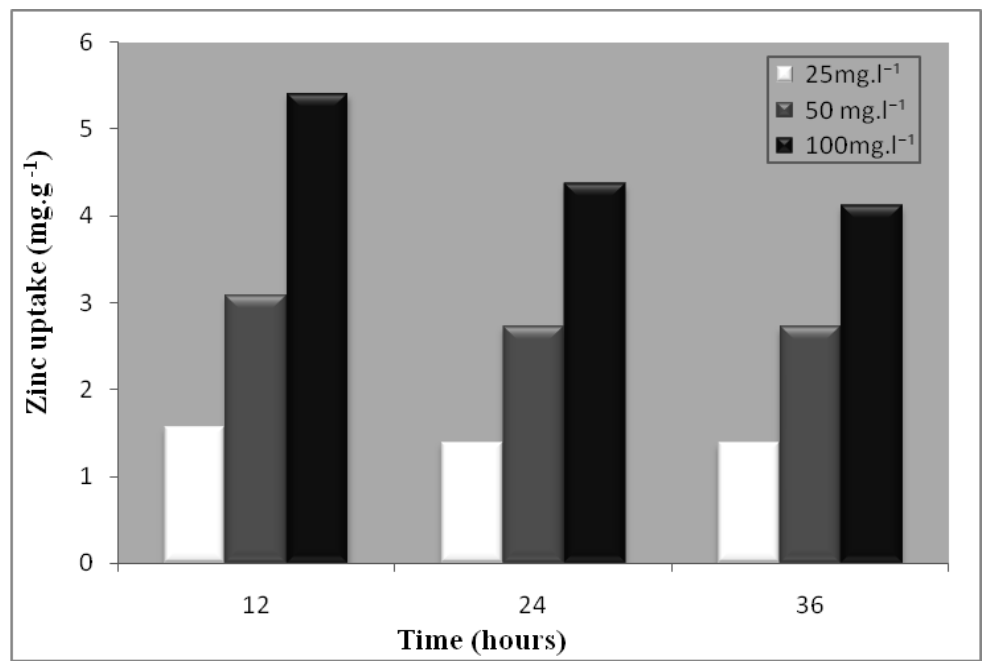

Fig.4: Removal percentage of zinc by Sargassum hornschuchii fresh biomass at different concentrations after 12, 24 and 36 hours.

\section{Effect of contact time:}

The experiment measures the effect of contact time (1-12 hours) on the biosorption of zinc by $P$. capillacea and S. hornschuchii fresh biomasses, in order to determine the shortest exposure time for maximum metal removal.

Biosorption of zinc by $P$. capillacea and $S$. hornschuchii with varying contact time was shown in Fig. 5 and 6. It is clear from the results that the removal of zinc by $P$. capillacea and $S$. hornschuchii increased with increase in contact time up to 3 and 5 hours, respectively. It decreased by very slight rate within 4-12 hours for $P$. capillacea and within 6-12 hours for S. hornschuchii. Science $P$. capillacea achieved zinc uptake and removal percentage of $4.08 \mathrm{mg} . \mathrm{g}^{-1}$ and $81.78 \%$, respectively after 3 hours, these values decreased with increase in time till reached $3.69 \mathrm{mg} . \mathrm{g}^{-1}$ and $73.96 \%$, respectively after 12 hours. Whereas the uptake $\left(1.83 \mathrm{mg} \cdot \mathrm{g}^{-1}\right)$ and removal percentage $(73.28 \%)$ of zinc by S. hornschuchii after 5 hours became $1.58 \mathrm{mg} \cdot \mathrm{g}^{-1} 63.40 \%$, respectively after 12 hours. Therefore the maximum zinc removal attained at contact time of 3 and 5 hours by $P$. capillacea and S. hornschuchii, respectively. 
Removal of zinc and its effect on some macromolecules and ultrastructure of Pterocladia capillacea ......

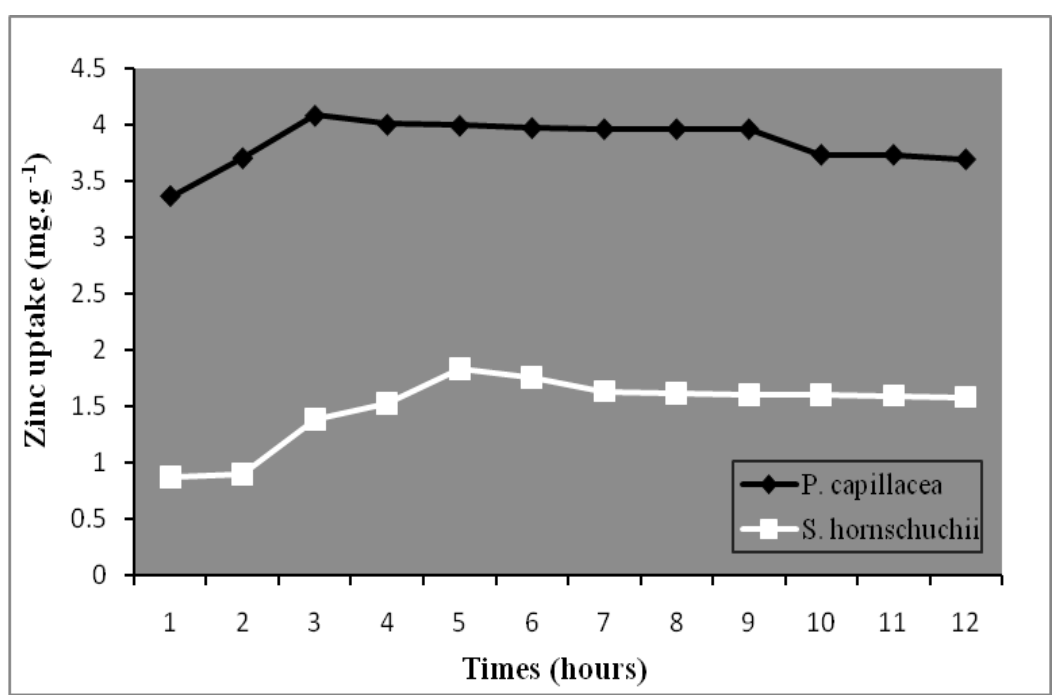

Fig. 5: Uptake of zinc by Pterocladia capillacea and Sargassum hornschuchii fresh biomasses at different contact times.

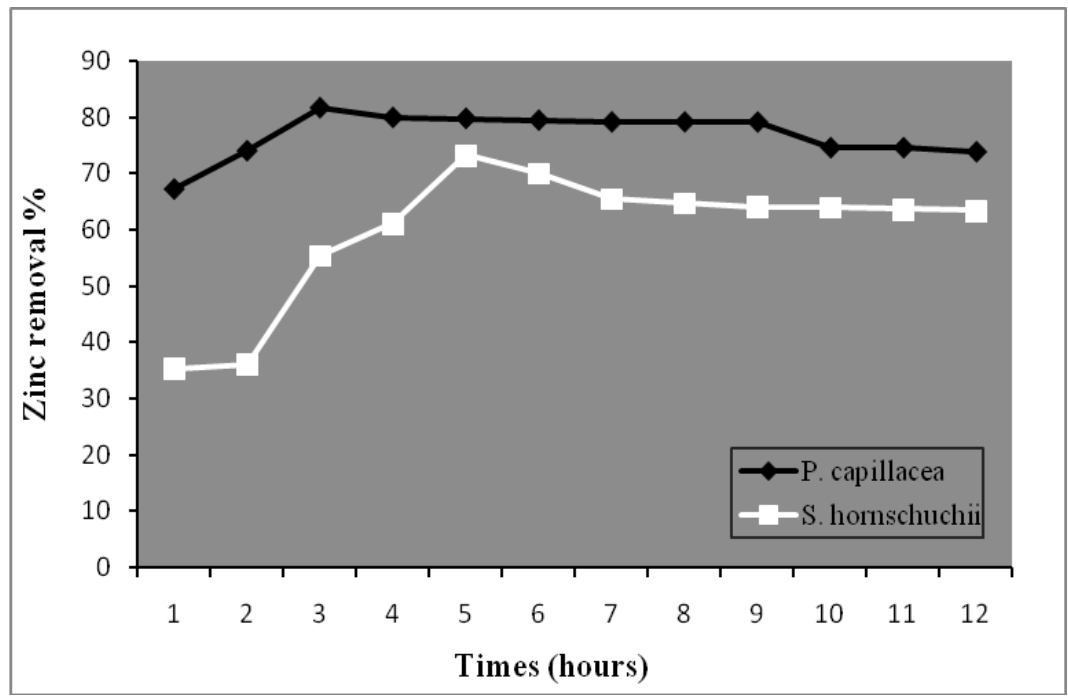

Fig. 6: Removal percentage of zinc by Pterocladia capillacea and Sargassum hornschuchii fresh biomasses at different contact times. 


\section{Effect of zinc on some metabolites and ultrastructure of Pterocladia capillacea and Sargassum hornschuchii.}

\section{Amino acids.}

Figure 7 showed the amino acids of P.capillacea before and after exposure to zinc $\left(50 \mathrm{mg} \cdot \mathrm{l}^{-1}\right)$. Generally, all amino acids of alga decreased compared to control after the exposure to zinc except tyrosine, phenylalanine and proline, which increased by $22.2,12.1$ and $3.4 \%$, respectively. Serine acid achieved the maximum decrease $(82.1 \%)$ by the exposure to zinc followed by glutamic acid which decreased by $78.8 \%$, while methionine achieved the minimum decrease (10.9\%). Other amino acids aspartic, threonine, glycine, alanine, valine, leucine, isoleucine and cystine decreased by 18.2, 19.5, 27.6, 21.8, 32.2, 13.8, 18 and $23.8 \%$.

The effect of zinc ( $\left.25 \mathrm{mg} . \mathrm{l}^{-1}\right)$ on the amino acids of S. hornschuchii was shown in Fig. 8. The results revealed that the exposure of $S$. hornschuchii to zinc classified its amino acids into two groups. The first group included the amino acids that increased by the exposure to zinc such as aspartic, glutamic, threonine, tyrosine, cystine, proline and serine, which increased by $18 \%, 92 \%, 3.6 \%, 11.8 \%$, $68.9 \%, 41.9 \%$ and fourfold, respectively compared to the control. Whereas the second group included the amino acids that decreased by the exposure to zinc such as glycine, alanine, valine, leucine, isoleucine, phenylalanine and methionine, which decreased by 5.8, 1.3, 8, 9.3, 7.7, 18.8 and 55.6\%, respectively. As observed, serine and methionine were the most affected amino acids by the exposure to zinc. However, the totals of acidic, aliphatic, sulphur-containing and secondary amino acids of $S$. hornschuchii increased after the exposure to zinc by $46.6,3.1,61$ and $41.9 \%$, respectively, while total aromatic amino acids decreased by $10.8 \%$ compared to the control.

It must be mentioned that the exposure of $P$. capillacea and $S$. hornschuchii to zinc caused statistically significant differences between the values of few amino acids as well as the values of total amino acids in treated and control biomasses. 


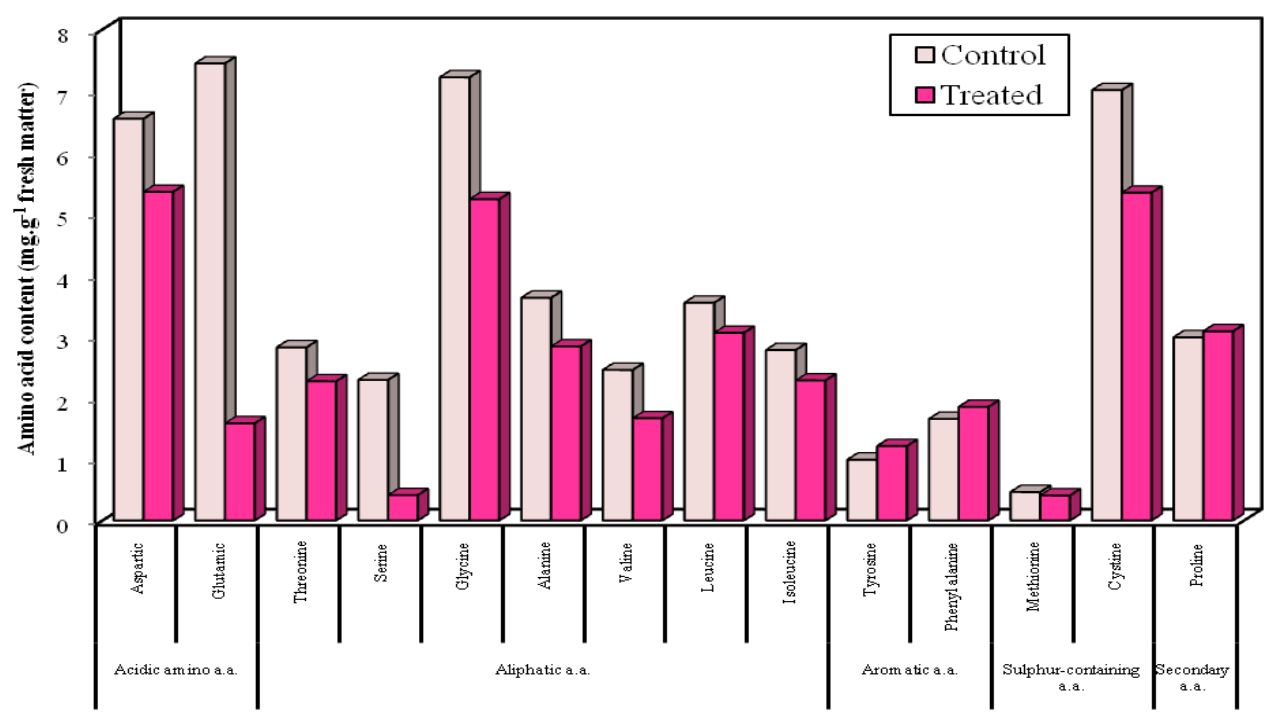

Fig. 7: Amino acids of Pterocladia capillacea before and after exposure to zinc (50 mg. ${ }^{-1}$ ) for 12 hours.

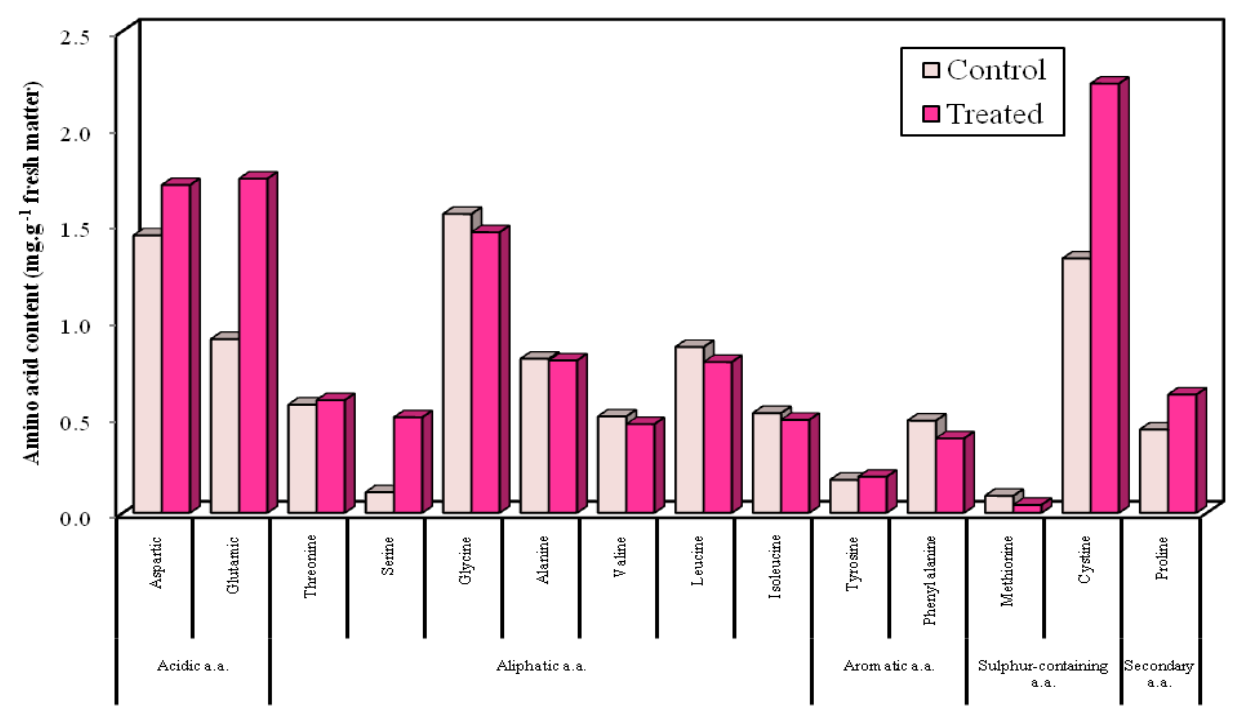

Fig. 8: Amino acids of Sargassum hornschuchii before and after exposure to zinc (25 mg..$^{-1}$ ) for 12 hours 


\section{Effect of algal dosage:}

\section{Fatty acids.}

Regarding the effect of zinc on the fatty acids content of $P$. capillacea, Fig. 9 indicated that $P$. capillacea suffered the disappearance of three fatty acids C11:0, C20:0 and C17:1 after exposure to zinc $\left(50 \mathrm{mg} . \mathrm{l}^{-1}\right)$. The saturated fatty acid C15:0 and the poly unsaturated fatty acids C18: 3 and C20:5 appeared in the treated biomass. Only C16:1 showed a slightly decrease, while other fatty acids increased compared to the control after exposure of biomass to zinc. C6:0, C8:0, C10:0, C12:0, C13:0, C17:0 and C15:1 showed greater increase than the other fatty acids, where they increased in range of 2:3 times compared to the control. The other fatty acids C14:0, C16:0, C18:0, C14:1, C18:2 and C22:6 elevated by $28.6,50.8,80,25,30.5$ and $91.8 \%$, respectively. The maximum increase (4.6 times) was recorded for $\mathrm{C} 20: 4$, while the minimum increase belonged to $\mathrm{C} 20: 3$, which increased by $3.7 \%$ compared to control. Totals of saturated, mono unsaturated and poly unsaturated fatty acids of alga increased by 1.9, 1.5 and 2.3 times, respectively after exposure to zinc.

Concerning the fatty acids content of S. hornschuchii before and after exposure to zinc ( $25 \mathrm{mg} . \mathrm{l}^{-1}$ ). Results in Fig. 10 revealed that all fatty acids of $S$. hornschuchii increased after exposure to zinc, except C6:0, C10:0, C18:0 and C18:2, which decreased by $88.3,50,70.3$, and $88 \%$, respectively. C16:1 achieved the highest value of increase ( 7.9 times), while C22:6 has the lowest value of increase (16.5\%). Both of C13:0 and C15:1 increased by about sixfold, while C14:0 increased by fourfold compared to the control. Each of C8:0, C12:0, C16:0, $\mathrm{C} 22: 1$ and C20:4 elevated by nearly 2 times after exposure of alga to zinc. The disappearance of the two fatty acids $\mathrm{C} 23: 0$ and $\mathrm{C} 20: 3$ was evident in treated biomass. The saturated fatty acid C15:0, mono unsaturated fatty acids C14:1 and C18:1 and poly unsaturated fatty acids $\mathrm{C} 20: 2$ and C18:3 can be recorded after the exposure of alga to zinc. The totals of saturated fatty acids and mono unsaturated fatty acids of S. hornschuchii increased by $45.5 \%$ and by 13.6 times, respectively after exposure to zinc, while the total of poly unsaturated fatty acids showed a decrease of $24.4 \%$. 


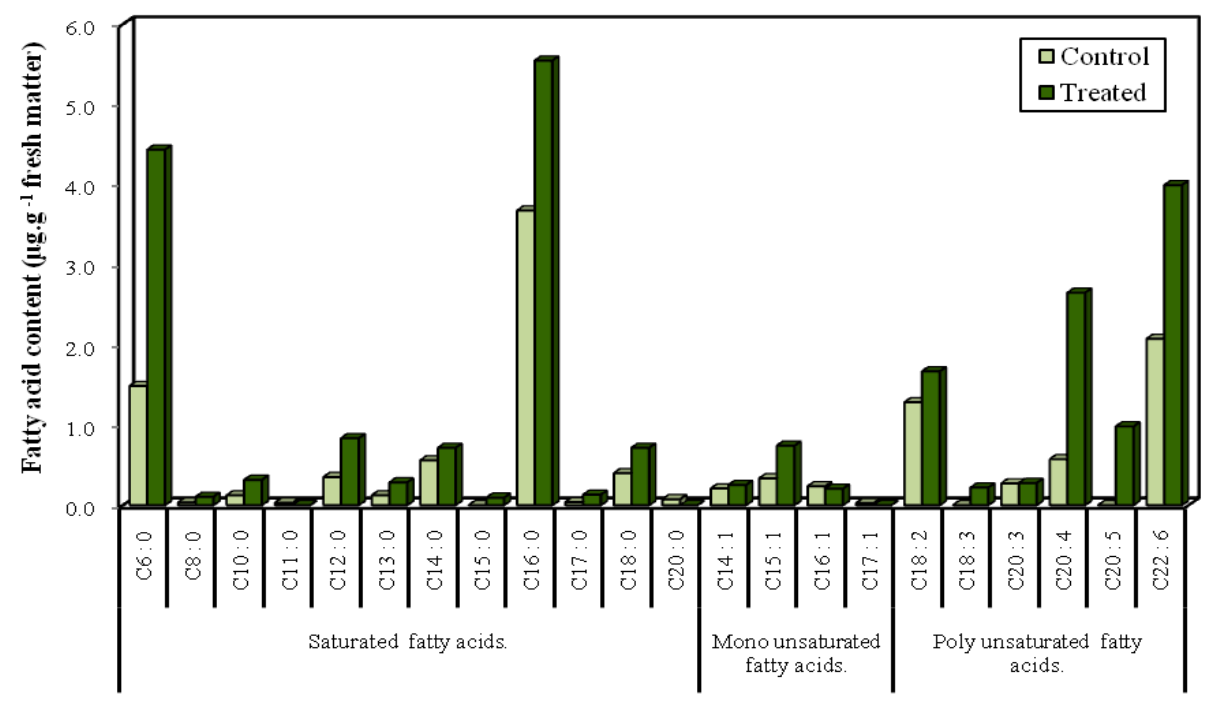

Fig. 9: Fatty acids content of Pterocladia capillacea before and after exposure to zinc $\left(50 \mathrm{mg}^{-1}{ }^{-1}\right)$ for 12 hours.

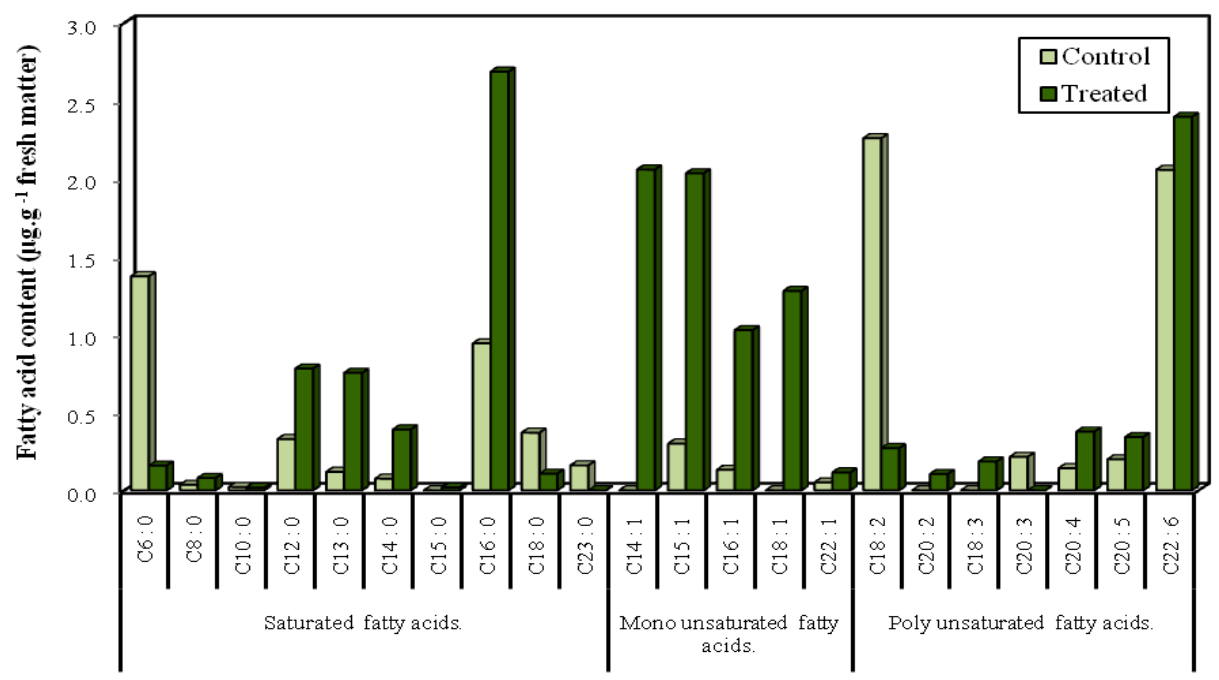

Fig. 10: Fatty acids content of Sargassum hornschuchii before and after exposure to zinc $\left(25 \mathrm{mg} . \mathrm{l}^{-1}\right)$ for 12 hours. 


\section{Protein.}

Table1 1 demonstrated the protein content of $P$. capillacea before and after exposure to chromium $\left(25 \mathrm{mg} . \mathrm{l}^{-1}\right)$ and zinc $\left(50 \mathrm{mg} . \mathrm{l}^{-1}\right)$. The results showed that the protein content of $P$. capillacea significantly decreased after the exposure to zinc. Regarding the protein content of $S$. hornschuchii before and after exposure to zinc $\left(25 \mathrm{mg} . \mathrm{l}^{-1}\right)$, table 1 indicated a valuable and significant increase in protein content of $S$. hornschuchii by more than three times compared to control after exposure to the studied metal.

Table (1): Protein content of Pterocladia capillacea and Sargassum hornschuchii before and after exposure to zinc $\left(50 \mathrm{mg}^{-l^{-1}}\right)$ and $\left(25 \mathrm{mg.l}^{-1}\right)$, respectively for 12 hours.

\begin{tabular}{|c|c|c|}
\hline $\begin{array}{c}\text { Protein content } \\
\text { (g. 100 g-1 fresh } \\
\text { matter) }\end{array}$ & $\begin{array}{c}\text { Pterocladia } \\
\text { capillacea }\end{array}$ & $\begin{array}{c}\text { Sargassum } \\
\text { hornschuchii }\end{array}$ \\
\hline Control & 11.86 & 1.3 \\
\hline Treated with $\mathrm{Zn}$ & $8.40^{*}$ & $4.18^{*}$ \\
\hline
\end{tabular}

\section{Ultra-structure of the studied algae.}

The electron micro-graph of $P$. capillacea before exposure to metal (Plate 1) showed the arrangement of the cell components and clear cell wall .

Electron microscopic screening of $P$. capillacea with zinc (50 mg. $\mathrm{l}^{-1}$ ) showed the irregularity of cell wall (Plate 2: A), disordering of cell inclusions (Plate 2: A \& B), and aggregation of cell components in a dense black manner inside the cell (Plate 2: B).

The electron micro-graph of $S$. hornschuchii before exposure to metal (Plate 3) referred to regular cell wall, arranged thyllakoids and arrangement of the cell components. Examination of S. hornschuchii ultra-structure with zinc (25 mg. $1^{-1}$ ) showed irregular cell wall, disordering of cell inclusions, destructive change in thyllakoids arrangement and slightly deviation of protoplast from the cell wall (Plate 4). 
Removal of zinc and its effect on some macromolecules and ultrastructure of Pterocladia capillacea ......

Plate (1): Transmission electron micro-graph of Pterocladia capillacea before exposure to metal.

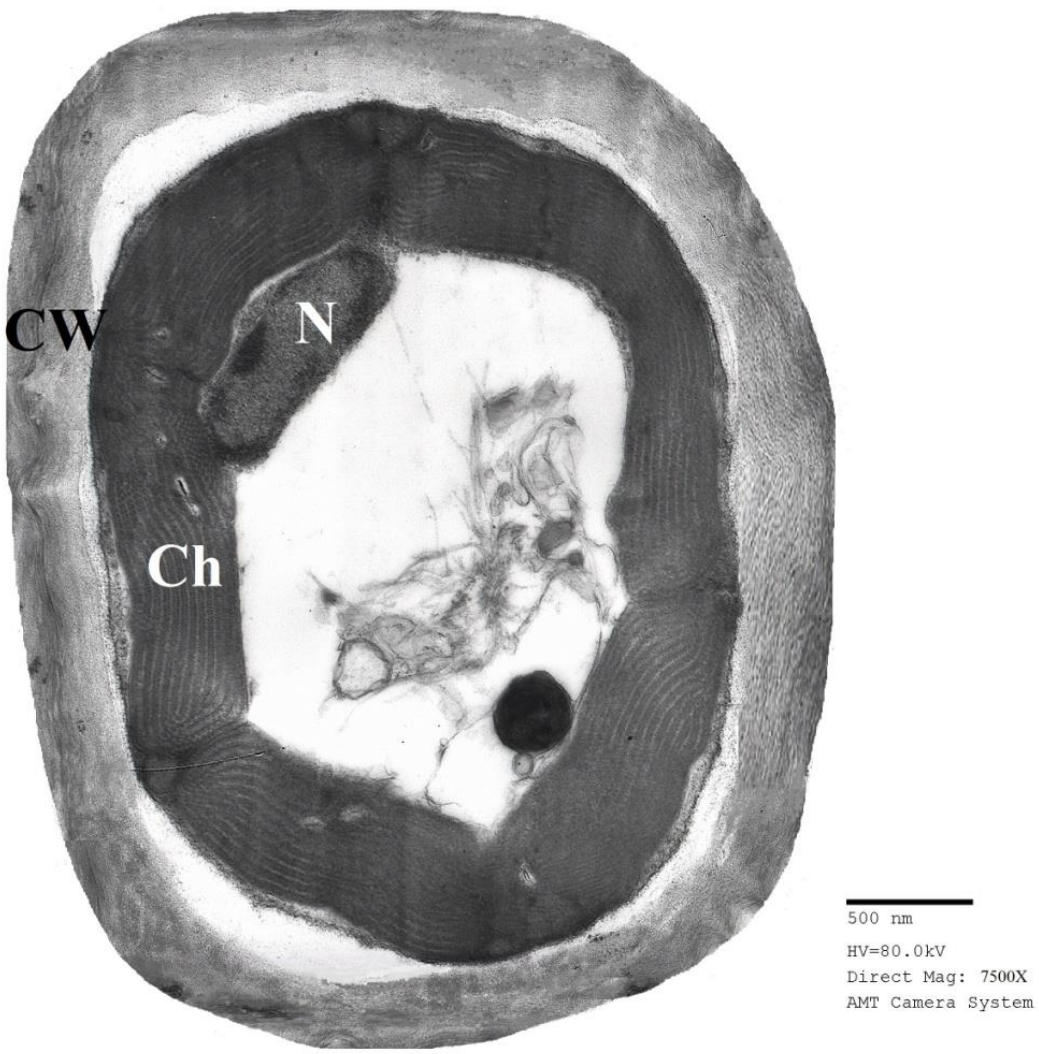

Ch: Chloroplast, CW: Cell Wall, N: Nucleus. 
Plate (2): Transmission electron micro-graph of Pterocladia capillacea after exposure to zinc $\left(50 \mathrm{mg}^{-1} \mathrm{l}^{-1}\right)$ for 12 hours.

(A)

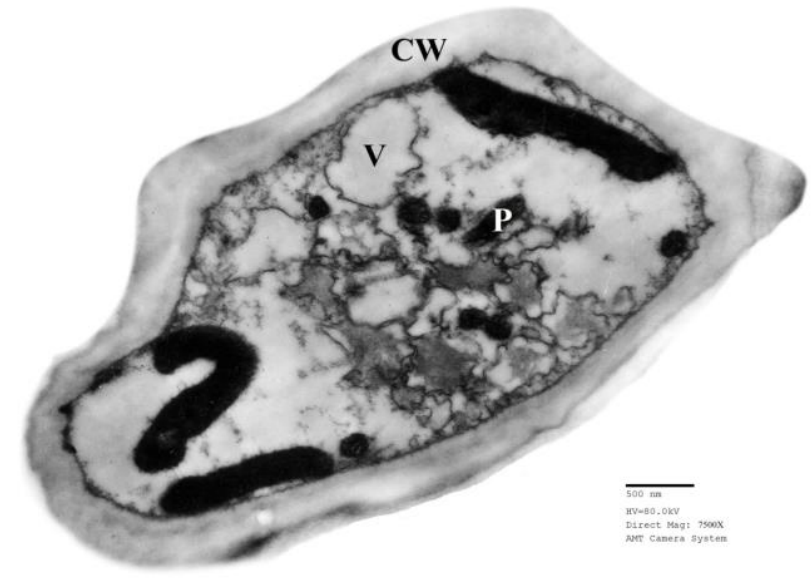

CW: Cell Wall, P: Precipitation of metal, V: Vacuole.

(B)

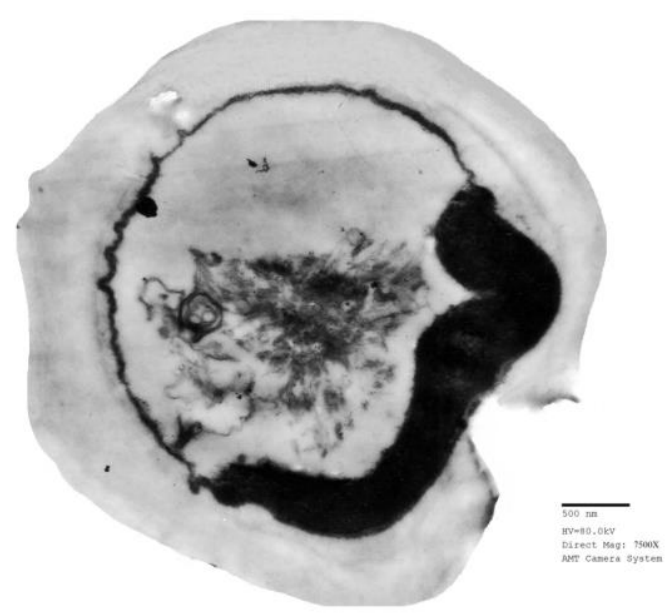


Removal of zinc and its effect on some macromolecules and ultrastructure of Pterocladia capillacea .......

Plate (3): Transmission electron micro-graph of Sargassum hornschuchii before exposure to metal.

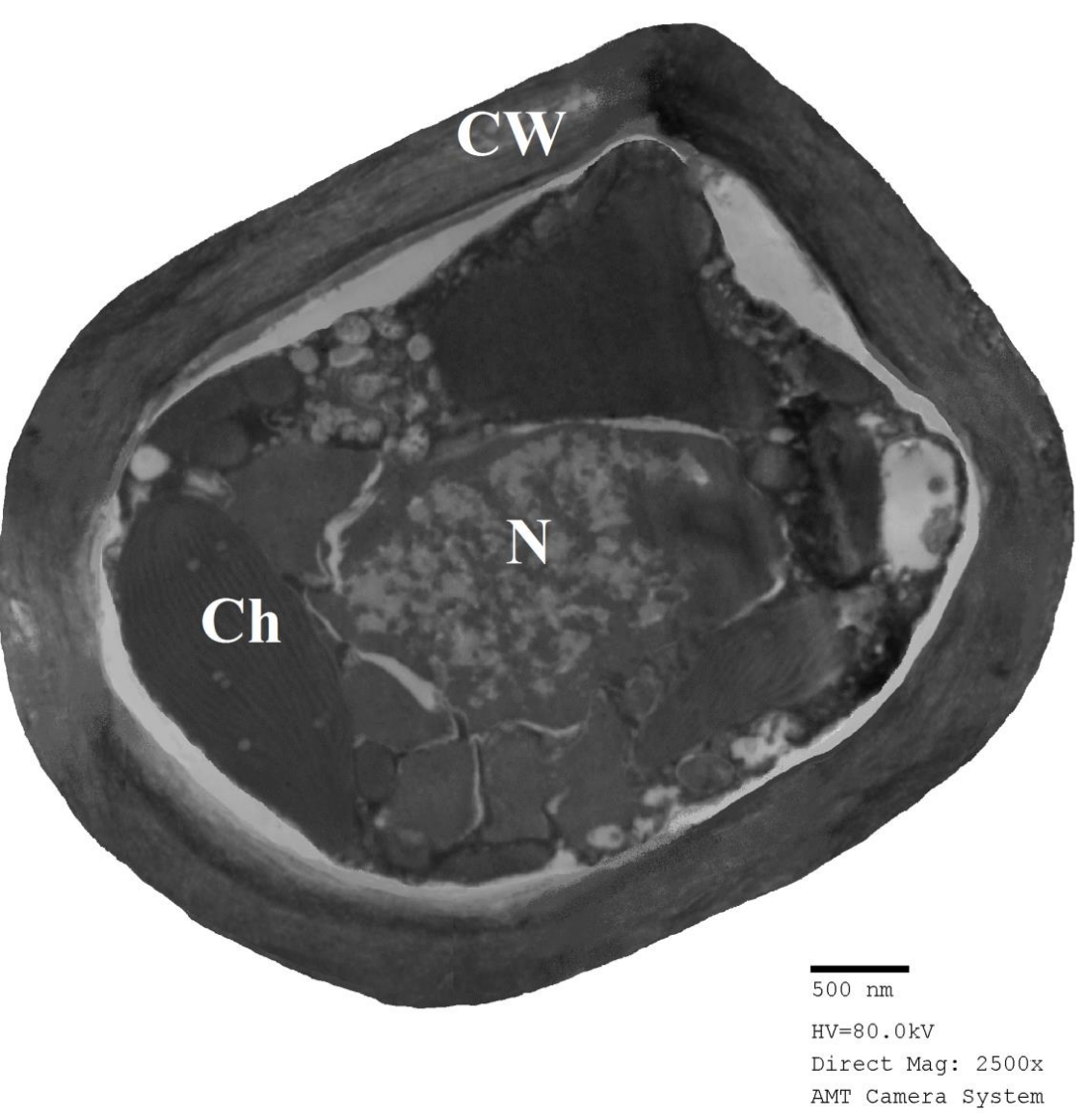

Ch: Chloroplast, CW: Cell Wall, N: Nucleus. 
Plate (4): Transmission electron micro-graph of Sargassum hornschuchii after exposure to zinc $\left(25 \mathrm{mg}^{-\mathrm{l}^{-1}}\right)$ for 12 hours.

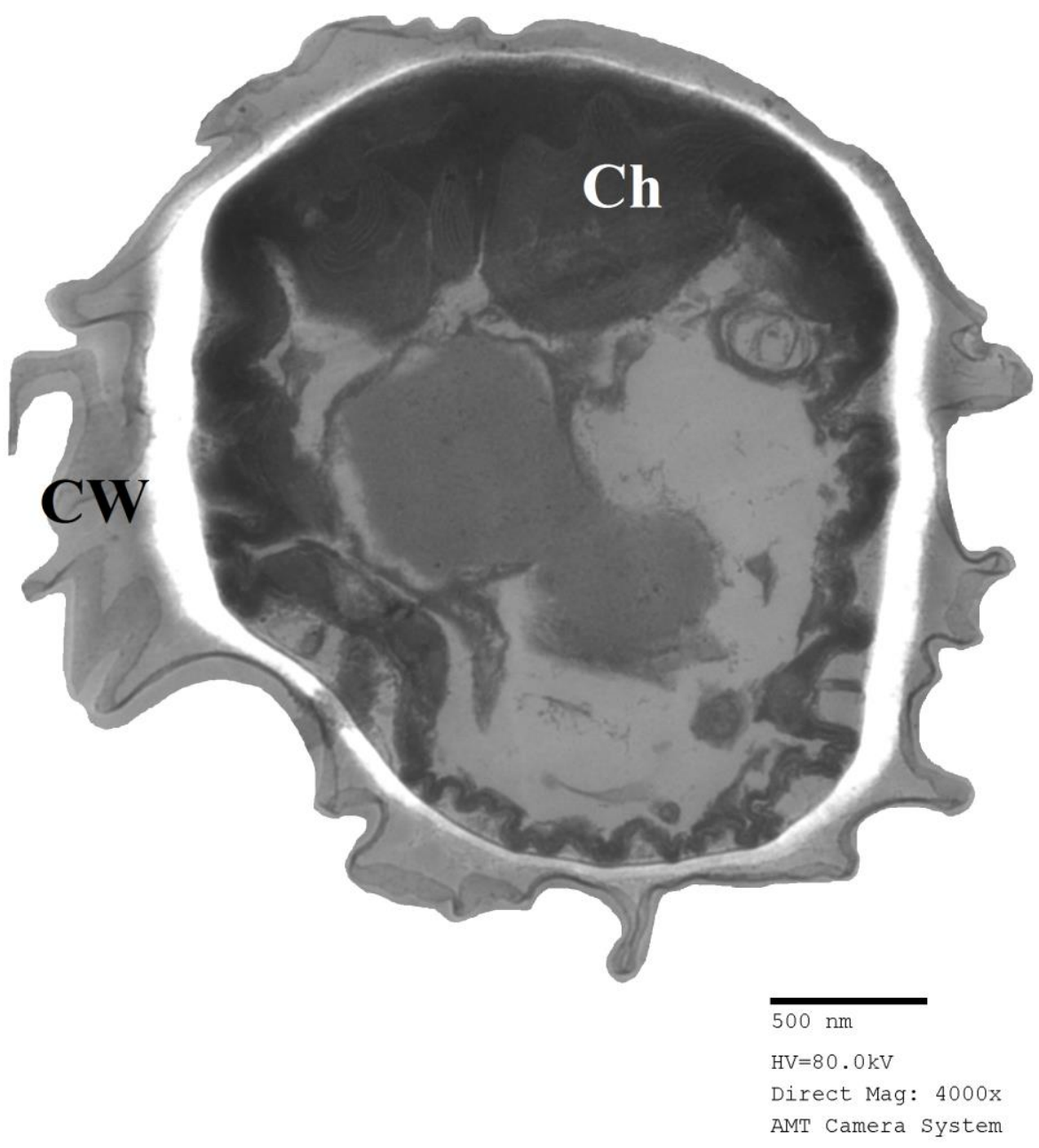

Ch: Chloroplast, CW: Cell Wall 


\section{Discussion}

After 12 hours, the concentration of zinc began to increase in solution, which means that the two algae cannot tolerate these heavy metals more than 12 hours. Under this stress the algae had died and these heavy metals were subsequently released back into the medium following lysing of the cells or possibly a simple diffusion process. This finidings similar to that of Baumann $\boldsymbol{e t}$ al. (2009), who proved that zinc was toxic heavy metal to seven species of marine macroalgae. In study of Choudhary et al. (2006), increased free radical generation was found in Spirulina platensis-S5 under heavy metal stress as indicated by the malondialdehyde (MDA) production, which is similar to the effect of heavy metals on higher plants (Dhir et al., 2004).This suggests that the toxic effect of heavy metals is probably exerted through free radical generation. Zinc was reported to be irreversibly bound to Ascophllum nodosum (Phaeophyta) (Skipnes et al., 1975) and Laminaria digitata (Bryan, 1969). Zinc inactive the cellular antioxidant pool and disrupt the metabolic balance, thus enhancing the load of reactive oxygen species (Stohs \& Bagchi, 1995 and Briat, 2002).

Experiment to determine the shortest exposure time (in range 1-12 hours) for maximum removal of zinc from the solution was conducted. The results indicated that the biosorption of zinc increased with increase in time and at certain point in time, it reached a value beyond which no more metal was further removed from solution and very slight decrease of biosorption occurred. This phenomenon was due to the fact that a large number of vacant surface sites were available for sorption during the initial stage of contact time period. As the vacant surface sites have been exhausted (i.e., saturated) with increase in time, the rate of solute transport from bulk to solid phase became limited. This Explanation was in agreement with that of Bishnoi et al. (2007) and Kumar et al. (2010a).

The decrease of the biosoption yield with increasing time may be attributed to many factors: the relative increases in the escaping tendency of metal ions from the solid phase to the solution, deactivating the biosorbents surface or destructing some active sites on the biosorbent surface due to bond ruptures (Meena $\boldsymbol{e t}$ al., 2005 and Romero-González et al., 2005) or due to the weakness of biosorptive forces between the active sites of the sorbents and the sorbet species (Yadav and Tyagi, 1987). 
Maximum uptake of zinc by $P$. capillacea occurred after 3 hours, while 5 hours caused maximum uptake of zinc by $S$. hornschuchii, this may indicate saturation of binding sites. Wang $\boldsymbol{e t}$ al., 2008 proved that contact time also affect the adsorption of heavy metal onto Laminaria japonica.

Initial metal concentration was found to have an important effect on the biosorption efficiencies of Pterocladia capillacea and Sargassum hornschuchii. Results in this study revealed that uptake of zinc by both fresh algal biomasses increased with increase in metal concentration, while their removal percentages showed variation in irregular trend. For example, the removal percentages of zinc by $P$. capillacea and $S$. hornschuchii, respectively decreased with increasing the metal concentration, and maximum biosorption was attained at the lower initial concentration $\left(25 \mathrm{mg} \cdot \mathrm{l}^{-1}\right)$. This is similar to the report by Kanchana et al. (2011) on biosorption of chromium (VI) on to Chlorella Species. On the other hand, the removal percentages of zinc by $P$. capillacea and $S$. hornschuchii, increased with increasing the initial concentration till reached 50 and $100 \mathrm{mg}^{-1} \mathrm{l}^{-1}$, respectively.

The increase of metal uptake was a result of increase in the driving force (i.e., concentration gradient). The initial metal ions concentration provides an important driving force to overcome all mass transfer resistances of $\mathrm{Zn}^{+2}$ between the aqueous and solid phases. This is the fundamental of the equilibrium between the sorption capacity and the final heavy metal concentration in the liquid phase, and this equilibrium is a very important factor that limits the sorption process. The same result was obtained by Rakesh et al. (2010). The uptake of heavy metals was found by Romera et al. (2008) to be not affected by increasing concentration of heavy metals, while Li et al. (2008) found that the absorption processes of chromium on algal cells was affected by the initial concentration of metal ions. The increase of biosorption efficiency by P.capillacea or S. hornschuchii with increasing the initial heavy metal concentration is in harmony with the findings of Onyancha et al. (2008) who accounted the results due to more competition at the higher concentration for the available binding sites.

The increase in metal removal percentage with increasing of initial concentration may be due to that at higher concentration, the number of metal ions available for competing at the binding sites of algal surfaces is more, thus increasing biosorption. The same explanation was obtained by De Phillips and Vincenzini (1998). Anjana et al. (2007) reported continuous increase in percent removal of heavy metal by Nostoc calcicola $\mathrm{HH}-12$ and Chroococcus sp. HH-11 with increasing initial metal ion concentration. 
On the other hand, the decrease in metal removal percentage with increasing of initial concentration may be attributed to lack of sufficient active sites on the biosorbent to accommodate much more metal ions. At lower concentrations, all metal ions present in solution could interact with the binding sites and thus the metal removal percentage was higher than those at higher metal ion concentrations. At higher concentrations, lower removal percentage was due to the saturation of sorption sites, therefore more metal ions were left unsorbed in solution. This result was in accordance with that of Devi et al. (2010) and Tripathi et al. (2011).

The obtained data revealed that zinc inhibited all detected amino acids of $P$. capillacea except the amino acid tyrosine, which showed a slight increase.

Proline content was found to increase in S. hornschuchii exposed to zinc. Exposure of Scenedesumus $s p$. to zinc increased the content of the amino acid proline (Tripathi and Gaur, 2004). It was suggested that proline protects cells from metal induced oxidative stress by scavenging ROS rather than by chelating metal ions.Proline has been found to play an important role in ameliorating environmental stress in plants and microorganisms including heavy metal stress and it was found to increase by the exposure of the alga Chlamydomonas reinhardtii to heavy metals (Rubinelli et al., 2002). Production of proline is one of the mechanisms by which many plants and algae respond to detoxify toxic heavy metals (Shah \& Dubey, 1998 and Verma, 1999). Although the mechanism of accumulation of proline in plants or plant parts exposed to stress is still unknown. It is suspected to be due to a decrease in the activity of the electron transport system (Alia et al., 1993) leading to accumulation of $\mathrm{NaDH}$ and $\mathrm{H}^{+}$. Proline accumulation (presumably through synthesis from glutamic acid) might be an adaptive mechanism for reducing (a) the level of accumulated $\mathrm{NADH}$ and (b) the acidity , $\left(2 \mathrm{NADH}+2 \mathrm{H}^{+}\right)$is used for synthesizing each molecule of proline from glutamic acid (Venekemp et al., 1987). The accumulation of proline in stressed plants is associated with reduced damage to membranes and proteins (Shah \& Dubey, 1998 and Verma, 1999). Proline synthesis has been implicated in the alleviation of cytoplasmic acidosis and may maintain $\mathrm{NADP}^{+} / \mathrm{NADPH}$ ratios at values compatible with metabolism (Hare and Cress, 1997). Proline has been proposed to act as osmoprotectant (Taylor 1996), a protein stabilizer (Shan \& Dubey, 1998), a metal chelator (Farago and Mullen, 1979), an inhibitor of lipid peroxidation (Mehta and Gaur, 1999), a hydroxyl radical scavenger (Alia et al., 2001). It is evident that there is no clear 
consensus regarding the mechanism (s) by which proline reduces heavy metal stress (Siripornadulsil et al., 2002).

$P$. capillacea showed the decrease of proteins by the exposure to zinc, while proteins of $S$. hornschuchii increased by exposure to zinc. EinickerLamas et al. (2002) observed the accumulation of proteins at the cells of Euglena gracilis treated with zinc and Noaman et al. (2003) proved that low concentrations of zinc caused stimulation of proteins of Synechococous leopoliensis and Dunaliella salina, while $1 \mathrm{mg} / \mathrm{l}$ and higher from zinc inhibited the biosynthesis of protein of both algae which may be attributed to the toxic action of the heavy metals on the enzymatic reactions responsible for protein biosynthesis (El-Naggar, 1993). The toxic effect of zinc at high concentrations may be attributed to its poisoning of enzymes as inhibitors of NADP-oxido reductase by signficantly lowering the cells supply of NADPH which affects the cells (Jeyechandran and George, 1991). Proteins of S. hornschuchii could be considered tolerant to zinc \& chromium, a phenomenon which was observed by many species of algae (Engel et al., 1981).

In the work of Choudhary et al. (2006), protein content increased with increasing metal ion concentration as reported earlier for Spirulina and Anabaena (Jetley et al. 2004 and Kumar et al., 2004). Increase in protein content under heavy metal stress in S.platensis indicates that it may contain a larger proportion of proline. Binding with metal ions due to the chelating ability of proline can also be a defense mechanism for survival.

The protein content of Anabaena doliolum exposed to the heavy metal nickel increased compared to the control which was accounted by the synthesis of metal binding protein, the metallothioneines helping the alga in chelation of toxic metal (Shukla et al., 2009). Similar increase in protein content is also observed by Lim et al. (2006). El-Gamal (2008) reported that there was decrease or increase in protein contents of Chroococcus dispersus, Microcystis fols-aquae and Microcoleus streestruqii in response to exposure to the heavy metal cadmium. Some authors observed that the synthesis of protein was repressed under heavy metal tested (Surosz \& Palinska, 2005). Novo et al. (2000) observed that specific proteins were induced by the heavy metal copper (16.28 and $42 \mathrm{kDa})$ and cadmium $(66 \mathrm{kDa})$, whereas proteins that had their synthesis repressed were observed for all the heavy metals tested . Protein induction was also observed in the cytosolic and membrane fraction from T.ferrooxidans LR cells grown in the presence of copper. 
All fatty acids of P.capillacea were found to increase by exposure to zinc except C16:1 which showed slight decrease , C11:0, C20:0 and C17:1 were completely disappeared from P.capillacea and C15: 0, C18:3 and absent C20:5, which appeared although they were absent at the control. Exposure of $S$. hornschuchii to zinc increased the contents of all fatty acids except C6:0, C10:0 and C18:0 which decreased and C14.1, C20:3 and C23:0 which completely disappeared, while C14:1, C18:1, C18:3, C20:2 and C15:0 appeared although they were absent at the contro. Einicker-Lamas et al. (2002) observed the accumulation of lipids at the cells of Euglena garcilis treated with zinc.

Total saturated and polyunsaturated fatty acids of both algae P.capillacea and S. hornschuchii treated by zinc were found to increased (Fig.9and 10 ). The increase of the total saturated fatty acids can be discussed by the fact that stress causes saturation of fatty acids in membrane lipids to decrease membrane lipid fluidity (Tatsuzawa et al., 1996), while Kumar et al., (2010b) found relatively higher contents of some polyunsaturated fatty acids (PUFA) of Ulva lactuca (than control) after exposure to cadmium indicating the prominence of PUFA in controlling the heavy metal stress. Polyunsaturated fatty acids are known in regulating membrane fluidity (Funk, 2001) and physiological processes under stress (Golecki and Drews, 1982).

The micrograph of the treated alga with zinc showed the irregularity of cell wall, disturbance to the cell inclusions and appearance of vacuoles and aggregation of cell components in a dense black manner inside the cells. The vacuole formation in $P$. capillacea treated by zinc is usually formed under stress conditions (Tillberg et al., 1979). Vacuoles may have a detoxification function (Noaman et al., 2003). The vacuoles play an important role in the regulation of metabolism and Sequestering metal ions in the vacuole is a method of maintaining low concentrations of ions (Gadd, 1993).

\section{References}

Alia, Mohanty, P. and Matysik, J. (2001). Effect of proline on the production of singlet oxygen. Amino Acid, 21: 195-200.

Anjana, K.; Kaushik, A.; Kiran, B. and Nisha, R. (2007). Biosorption of $\mathrm{Cr}(\mathrm{VI})$ by immobilized biomass of two indigenous strains of cyanobacteria 
isolated from metal contaminated soil. Journal of Hazardous Materials, 148: 383-386.

Basha, S.; Murthy, Z.V.P. and Jha, B. (2008). Biosorption of hexavalent chromium by chemically modified seaweed, Cystoseira indica. Chemical Engineering Journal, 137 (3): 480-488.

Baumann, H.A.; Morrison, L. and Stengel, D.B. (2009). Metal accumulation and toxicity measured by PAM - Chlorophyll fluorescence in seven species of marine macroalgae. Ecotoxicology and Environmental Safety, 72 (4): 1063-1075.

Bhattacharya, A.K.; Mandal, S.N. and Das, S.K. (2006). Adsorption of Zn(II) from aqueous solution by using different adsorbents. Chemical Engineering Journal, 123: 43-51.

Bishnoi, N.R.; Kumar, R.; Kumar, S. and Rani, S. (2007). Biosorption of $\mathrm{Cr}$ (III) from aqueous solution using algal biomass Spirogyra spp. Journal of Hazardous Materials, 145 (1-2): 142-147.

Briat, J.F. (2002). Metal ion activated oxidative stress and its control. In: Inze, D., Montagu, M.V. (Eds.), Oxidative Stress in Plants. Taylor and Francis, New York, pp: 171-189.

Briggs, C. J. (1993). Competition among parasitoid species on a stage-structured host, and its effect on host suppression. American Naturalist, 141: 372-397.

Bryan, G.W. (1969). The absorption of zinc and other metals by the brown seaweed Laminaria digitata. Journal of the Marine Biological Association of the United Kingdom, 49: 225-243.

Carson, B.L.; Ellis, H.V. and Mc-Cann, J.L. (1986). Toxicology and biological monitoring of metals in humans, Lewis publishers, Chelsea, Michigan., 65: 297.

Choudhary, M.; Jetley, U.K; Khan, M. A.; Zutshi, S. and Fatma, T. (2006). Effect of heavy metal stress on proline, malondialdehyde, and superoxide dismutase activity in the cyanobacterium Spirulina platensis-S5. Ecotoxicology and Environmental Safety, 66 (2): 204-209.

De Phillips, R. and Vincenzini, M. (1998). Exocellular polysaccharides from cyanobacteria and their possible application. FEMS (a Federation of European Microbiological Societies) Microbiology Reviews, 22: 151-175.

Devi, B.S.; Mary, S.J.; Rajendran, S.; Manimaran, N.; Rengan, P.; Jayasundari, J. and Mannivannan, M. (2010). Removal of mercury by biosorption onto sphaeroplea algae. Zaštita Materijala, 51 (4): 227.

Egan, H.; Kirk, R.S. and Sawyer, R. (1981). Pearson's Chemical Analysis of Foods, 8th Edition. Churchill Livingstone, Edinburgh London Melbourne and New York, pp: 15-18. 
Einicker-Lamas, M.; Mezian, G.A.; Fernandes, T.B.; Silva, F.L.; Guerra, F.; Miranda, K.; Attias, M. and Oliveira, M.M. (2002). Euglena gracilis as a model for the study of $\mathrm{Cu}^{+2}$ and $\mathrm{Zn}^{+2}$ toxicity and accumulation in eukaryotic cells. Environmental Pollution, 120 (3): 779-786.

El-Gamal, A.D. (2008). Protein Profile Changes in Chrococcus dispersus, Microcystis flos-aquae and Microcoleus steenstruqii in Response to Cadmium Treatments. JKAU (Journal of King Abdulaziz University): Science, 20 (2): 131-148.

El-Naggar, A.H. (1993). Growth and some metabolic activities of Chlorella and Senedesmus in relation to heavy metal water pollution in Gharbia governorate. Ph.D. thesis, Tanta University, Egypt.

Engel, D.W.; Sunda, W.G. and Fowler, B.A. (1981). Factors affecting trace metals uptake and toxicity to estuarine organisms. I. Enviromental parameters. In Biological Monitoring of Marine Pollutants. (J.F., Vernberg, A. Calabrese, F.P. Thurberg and W.B. Vernberg, eds). Academic Press, New York, pp: 127-144.

FAO/WHO (1973). Energy and Protein requirements. Technical Report No 522. Ad Hoc Expert Committee. Rome: FAO/WHO.

Farago, M.E., and Mullen, W.A. (1979). Plants which accumulate metals. Part IV. A possible copper-proline complex from the roots of Armeria maritima. Inorganica Chimica Acta, 32: L93-L94.

Funk, C.D. (2001). Prostaglandins and leukotrienes: advances in eicosanoids biology. Science, 294: 1871-1875.

Gadd, G. M. (1993). Interaction of fungi with toxic metals. Phytologist, 124: 25-60.

Golecki, J. R. and Drews, G. (1982). The Biology of the Cyanobacteria (Carr, N. G. and Whitton, B. A. Eds.) Blackwell, London. pp. 125-141.

Hare, P. D. and Cress, W. A. (1997). Metabolism implications of stressinduced proline accumulation in plants. Plant Growth Regul., 21, 79-102.

Hashim, M.A. and Chu, K.H. (2004). Biosorption of cadmium by brown, green and red seaweeds. Chemical Engineering Journal, 97, 249-255.

Jetley, U.K., Choudhary, M. and Fatma, T. (2004). Evaluation of biochemical productivity cyonobacterium Spirulina platensis-S5. under heavy metal stress. Asian J. Chem. 16 (3-4): 1524-1528.

Jones, D. B. (1931). Factors for converting percentages of nitrogen in foods and feeds into percentages of protein. USDA Circular Number 183. Washington, DC: United States, Department of Agriculture, pp: 1-21. 
Kumar, M.; Kumari, P.; Gupta, V.; Anisha, P. A.; Reddy, C. R. K. and Jha, B. (2010a). Differential responses to cadmium induced oxidative stress in marine macroalga Ulva lactuca (Ulvales, Chlorophyta). Biometals, 23 (2): 315-325.

Kumar, P.S.; Ramakrishnan, K. and Gayathri, R. (2010b). Removal of nickel(II) from aqueous solutions by Ceralite IR 120 cationic exchange resins. Journal of Engineering Science and Technology, 5 (2): 232 - 243.

Kumar, S.; Jetley, U.K. and Fatma, T. (2004). Tolerance of Spirulina platensis- S5 and Anabaena sp to endosulfan an organochlorine pesticide. Ann. Plant Physiol. 18 (2): 103-107.

Lim, C.Y.; Yoo, Y.H.; Sidharthan, M.; Ma, C.W.; Bang, I.C.; Kim, J.M.; Lee, K.S.; Park, N.S. and Shin, H.W. (2006). Effects of copper (I) oxide on growth and biochemical compositions of two marine microalga. Journal of Environmental Biology, 27 (3): 461-466.

Meena, A.K.; Mishra, G.K.; Rai, P.K.; Rajagopal, C. and Nagar, P.N. (2005). Removal of heavy metal ions from aqueous solutions using carbon aerogel as an adsorbent. Journal of Hazardous Materials, B., 122: 161-170.

Mehta, S.K., and Gaur, J.P. (1999). Heavy-metal-induced proline accumulation and its role in ameliorating metal toxicity in Chlorella vulgaris. New Phytologist, 143: 253-259.

Noaman, N. H.; Khaleafa, A. M.; Shalaan, S. H. and Abdel Aziz, W. M. (2003). Ultrastructural alterations and amino acids contents changing of Synechoccus leopoliensis and Dunaliella salina under environmental pollution stresses. Egyptian Journal of Biotechnology, 14: 31-44.

Noaman, N. H.; Khaleafa, A. M.; Shalaan, S. H. and Abdel Aziz, W. M. (2001). Impact of some heavy metals to Synechoccus leopoliensis and Dunaliella salina. Egyptian Journal of Biotechnology, 1-16.

Novo, M.M.; De Silva, A.C.; Ronaldo, M.; Paula, C.; Antonia, C.; Oswaldo, Jr.G. and Ottoboni Laura, M.M. (2000). Thiobacillus ferrooxidans response to copper and other heavy metals: growth, protein synthesis and protein phosphorylation, Antonie Van Leeuwenhoek, 77: 187-195.

Onyancha, D.; Mavura, W.; Nigla, J.C.; Ongoma, P. and Chacha, J. (2008). Studies of chromium removal from tannery wastewaters by algae biosorbents, Spirogyra condensate and Rhizoclonium hieroglyphicum. Journal of Hazardous Materials, 158: 605-614.

Pinto, E.; Signaud-Kutner, T.C.S.; Leitao, M.A.S.; Okamoto, O.K.; Morse, D. and Colepicolo, P. (2003). Heavy metal-induced oxidative stress in algae. Journal of Phycology, 39: 1008-1018. 
Radwan, S.S. (1978). Coupling of two dimension thin layer chromatograph with gas chromatography for the quantitative analysis of lipids classes and their constituent fatty acid. Journal of Chromatographic Science, 16: 538-542.

Rakesh, N.; Kalpana, P.; Rao, L.N.; Naidu, T.V.R. and Rao, M.V. (2010). Removal of zinc ions from aqueous solution by Ficus Benghalensis L.: equilibrium and kinetic studies. International Journal of Engineering Studies, 2 (1): 15-28.

Romera, E.; González, F.; Ballester, A.; Blázquez, M.L. and Muñoz, J.A. (2008). Biosorption of heavy metals by Fucus spiralis. Bioresource Technology, 99: 4684-4693.

Romero-González, J.; Peralta-Videa, J.R.; Rodríguez, E.; Ramirez, S.L. and Gardea- Torresdey, J.L. (2005). Determination of thermodynamic parameters of $\mathrm{Cr}(\mathrm{VI})$ adsorption from aqueous solution onto Agave lechuguilla biomass. Journal of Chemical Thermodynamics, 37 (4): 343347.

Rubinelli, P.; Siripornadulsil, S.; Gao-Rubinelli, F. and Sayre, R.T. (2002). Cadmium- and iron-stress-inducible gene expression in the green alga Chlamydomonas reinhardtii: Evidence for $\mathrm{H} 43$ protein function in iron assimilation. Planta, 215 (1): 1-13.

Shah, K., and Dubey, R.S. (1998). Effect of cadmium on proline accumulation and ribonuclease activity in rice seedlings: Role of proline as a possible enzyme protectant. Biologia Plantarum, 40: 121-130.

Siripornadulsil, S.; Traina, S.; Verma, D. P. S. and Sayre, R. T. (2002). Molecular mechanisms of proline-mediated tolerance to toxic heavy metals in transgenic microalgae. Plant Cell, 14: 2837-2847.

Skipnes, O.; Roald, T. and Haug, A. (1975). Uptake of zinc and strontium by brown algae. Physiologia Plantarum, 34: 314-320.

Stohs, S.J. and Bagchi, D. (1995). Oxidative mechanisms in the toxicity of metal ions. Free Radical Biology and Medicine, 18 (2): 321-336.

Sunda, W.G. (1988-1989). Trace metal interactions with marine phytoplankton. Biol. Oceanogr., 6: 411- 442.

Surosz, W. and Palinska, K.A. (2005). Effects of heavy-metal stress on cyanobacterium Anabaena flos-aquae. Archives of Environmental Contamination and Toxicology, 48 (1): 40-48.

Tatsuzawa, H.; Takizawa, E.; Wada, M. and Yamamoto, Y. (1996). Fatty acid and lipid composition of the acidophilic green algae Chlamydomonas sp. Journal of Phycology, 32: 598-601. 
Taylor, C.B. (1996). Proline and water deficit: Ups, downs, ins and outs. Plant Cell, 8: 1221-1224.

Tillberg, J. E.; Barnarad, T. and Rowley, J., (1979). X-ray microanalysis of phosphorus in Scenedesmus obtusiusculus. Physiologia Plantarum, 47(1), 34-38.

Tripathi, B.N. and Gaur, J.P. (2004). Relationship between copper and zincinduced oxidative stress and proline accumulation in Scenedesmus sp. Planta, 219 (3): 397-404.

Tripathi, M.; Mishra, S.S.; Tripathi, V.R. and Garg, S.K. (2011). Predictive approach for simultaneous biosorption of hexavalent chromium and pentachlorophenol degradation by Bacillus cereus RMLAU1. African Journal of Biotechnology, 10 (32): 6052-6061.

Verma, D.P.S. (1999). Osmotic stress tolerance in plants: Role of proline and sulfur metabolisms. In Molecular Responses to Cold, Drought, Heat and Salt Stress in Higher Plants, K. Shinozaki and K. Yamaguchi-Shinozaki, eds (Austin, TX: R.G. Landers), pp: 153-168.

Volesky, B. and Holan, Z. (1995). Biosorption of heavy metals. Biotechnology Progress, 11 (3): 235-250.

Wang, X.S., Li, Z.Z. and Sun, C. (2008). Removal of Cr(VI) from aqueous solutions by low-cost biosorbents: Marine macroalgae and agricultural byproducts. Journal of Hazardous Materials, 153: 1176-1184.

Winder, K. and Eggum, O.B. (1966). Protein hydrolysis. A description of the method used at the department of animal physiology in Copenhagen. Acta Agriculture Scandinavia, 16-115.

Yadav, K.P and Tyagi, B.S. (1987). Fly-ash for the treatment of Cd-rich effluent. Environmental Technology Letters, 8: 225-234. 